\title{
REVOLUSI PEMERINTAHAN, SUDAHKAH BEREVOLUSI? KOLOKASI ADJEKTIVA KATA "INDONESIA" DALAM COCA DAN COHA PADA PERIODE PEMERINTAHAN ORDE LAMA, ORDE BARU DAN ERA REFORMASI
}

\author{
Almira Fidela Artha \\ airafidel@gmail.com \\ Universitas Internasional Semen Indonesia
}

\begin{abstract}
Historically, Indonesia's system of government is divided into three periods, namely The old order, The new order and Reformation. Every government order has a different and changing image of the nation. This change can be analyzed by looking at the collocation of adjectives attached to the word "Indonesia" in the corpus of COCA (Corpus of Contemporary American English) and COHA (Corpus of Historical American English). The focus of this study is the collocation differences and similarities of the word "Indonesia" in three dimensions of time, namely The old order, The new order and Reformation. By using discourse analysis from Djik (1997), it is expected that the image of Indonesian nation in the eyes of the world represented by America in three periods of government can be seen. The results of this study indicated that the collocation of adjectival adjectives which follow the word "Indonesia" changed every period of government and the turn of this much backed by the context of the situation or historical record that occurred at each period.
\end{abstract}

Key Words: adjective, collocation, corpus, linguistic corpus, Indonesia

\section{Abstrak}

Berdasarkan sejarah, sistem pemerintahan Indonesia terbagi menjadi tiga periode, yaitu Orde Lama, orde Baru dan Reformasi. Setiap orde pemerintahan pasti memiliki citra bangsa yang berbeda dan berubah. Perubahan ini dapat dianalisis dengan melihat kolokasi adjektiva yang melekat pada kata "Indonesia" dalam korpus COCA(Corpus of Contemporary American English) dan COHA (Corpus of Historical American English). Fokus pada penelitian ini adalah perbedaan dan persamaan kolokasi adjektiva kata "Indonesia" dalam tiga dimensi waktu, yakni orde lama, orde baru, era reformasi. Dengan menggunakan analisis wacana (Discourse Analysis) dari Djik (1997), diharapkan citra bangsa Indonesia di mata dunia diwakili oleh Amerika dalam tiga periode pemerintahan dapat terlihat. Hasil penelitian ini menunjukkan bawasannya kolokasi adjektiva yang mengikuti kata "Indonesia" berganti setiap periode pemerintahan dan pergantian ini banyak dilatarbelakangi dengan konteks situasi atau catatan sejarah yang terjadi pada setiap periode.

Kata Kunci: adjektiva, kolokasi, korpus, linguistik korpus, Indonesia

\section{PENDAHULUAN}

"Kami bangsa Indonesia dengan ini menjatakan kemerdekaan Indonesia. Hal-hal jang mengenai pemindahan kekoeasaan d.l.l., diselenggarakan dengan tjara seksama dan dalam tempo jang sesingkat-singkatnja”. (Departemen Pendidikan Kewarganegaraan UPI, 2017) 
Indonesia telah merdeka dan diakui kedaulatannya sebagai negara yang berdaulat kurang lebih sudah selama tujuh puluh tahun semenjak teks Proklamasi tersebut diatas disiarkan pada tanggal 17 Agustus 1945. Selama tujuh puluh tahun kemerdekaaan Indonesia, salah satu rentetan sejarah yang terukir sebagai pelajaran berharga bangsa adalah sejarah politiknya. Dalam sejarah politiknya sistem pemerintahan Indonesia terbagi menjadi tiga periode yaitu (1) pemerintahan orde lama yaitu diawali pada tahun 1945-1967 dibawah masa pemerintahan Presiden Soekarno, (2) pemerintahan orde baru diprakarsai oleh Presiden Soeharto pada tahun 1968-1998 dan (3) era reformasi pada tahun 1999 hingga saat ini masih berjalan. Dalam banyak hal, setiap masa pemerintahan memiliki perbedaan satu sama lain misalnya dalam hal hak asasi manusia (Trinugraha, 2015; Amaruli \& Utama, 2015) birokrasi (Ginting \& Haryati, 2011), dan lain sebagainya.

Dalam setiap periode pemerintahan, citra Indonesia sebagai bangsa dan negara yang berdaulat bisa jadi berubah. Sebagai contoh, dalam awal kemerdekaannya atau pada masa orde lama, Indonesia dianggap sebagai negara baru yang merupakan negara yang memiliki man-power terbanyak dan terkuat, wilayah yang terbesar, dan proklamasi anti penindasan paling tegas. Selain itu, falsafah kenegaraannya benarbenar merupakan refleksi kepribadian sendiri, dengan perspektif untuk menciptakan kehidupan bangsanya yang adil dan makmur (Dekker, 1989). Sedangkan dalam era orde lama, menurut Samuel (2010) Indonesia menuju dalam masa perkembangan yang sering disebut sebagai era modernisasi. Hingga berlanjut pada era reformasi, atau era perubahan. Perubahan citra Indonesia ini sangat memungkinkan dipengaruhi oleh perbedaan pencapaian pada setiap era pemerintahan, konflik-konflik yang terjadi, tingkat kesuksesan politik, dll.

Secara ilmiah, citra Indonesia dalam setiap era pemerintahan ini bisa diteliti dengan mencari kolokasi adjektiva yang melekat pada kata Indonesia itu sendiri. Kolokasi merupakan hubungan antara kata dan bentuk kata individual yang sering terjadi, bersama-sama dan berkaitan (Stubbs, 2009). Dalam KBBI disebutkan bahwa Kolokasi merupakan asosiasi tetap antara kata dan kata lain dalam lingkungan yang sama. Kolokasi merupakan sebuah fenomena bahwa setiap kata tertentu yang mungkin terjadi kombinasi dengan kata lainnya dalam konteks tertentu (Baker dkk. (2006). Artinya adalah setiap kata dalam konteks tertentu akan berasosisi atau berkorelasi dengan kata lain, atau bisa dikatakan bahwa setiap kata bisa memiliki kedekatan dengan kata lain yang nantinya dalam konteks tertentu bisa mengandung makna. Oleh sebab itu dengan mengetahui kolokasi adjektiva kata Indonesia, citra Indonesia berdasarkan periode pemerintahan akan mudah diketahui. 
Contoh dari kolokasi adalah sebuah kata keterangan atau adverb seperti extremely dan greatly ternyata memiliki kecenderungan kata pendamping atau kolokasi yang berbeda. Kennedy (Kennedy, 2003) menyebutkan bahwa kata extremely dalam BNC dekat sekali atau sering berpasangan dengan kata rare, kemudian untuk kata greatly sangat dekat atau berkolokasi dengan kata different. Oleh karena itu, kedekatan atau kolokasi kata Indonesia yang dibagi dalam tiga periode pemerintahan ini diharapkan dapat menunjukan dengan jelas citra kata Indonesia secara aktual.

Untuk mengarahkan penelitian ini ada satu penelitian terkait yang mirip dan membahas mengenai kolokasi sebuah kata, yaitu penelitian oleh Kwary \& Arum (2011). Penelitian ini terfokus pada perbedaan dan persamaan kolokasi adjektiva yang melekat pada laki laki (men) dan perempuan (women) selama periode pemerintahan Presiden Lincoln dan Obama. Dalam penelitian ini menemukan bahwa terdapat persamaan serta perbedaan kolokasi adjektiva yang melekat pada (men) dan perempuan (women) dalam dua dimensi waktu yang berbeda.

Berbeda dengan penelitian terkait, dalam penelitian ini tidak hanya terfokus pada perbedaan dan persamaan kolokasi adjektiva sebuah kata namun juga meneliti mengenai bagaimana kolokasi adjektiva dapat menunjukkan perbedaan citra Indonesia dalam tiga dimensi waktu pemerintahan yaitu dalam periode orde lama, orde baru, dan reformasi dilihat dari frekuensi kebermunculan di COCA dan COHA. Peneliti tidak hanya meneliti asosiasi kata apa saja yang melekat dalam kata Indonesia (kolokasi) namun juga meneliti lebih dalam alasan kemunculan kata tersebut dengan menggunakan Studi wacana (Discouse Studies) oleh Djik (1997).

Djik (1997) mengatakan bahwa discourse studies are about talk and text in context, artinya adalah discourse atau bahasa tidak hanya mengenai teks dan percakapan melainkan juga mengenai konteks, yaitu sebuah situasi sosial atau communicative event yang secara sistematik bekerja mempengaruhi teks dan percakapan. Kolokasi adjektiva yang muncul beriringan dengan kata Indonesia merupakan salah satu dari properti teks yang syarat dengan makna. Menerapkan discourse analysis dalam meneliti konteks situasi dalam kolokasi adjektiva kata Indonesia diharapkan citra kata Indonesia dapat terlihat dengan jelas.

Dengan mengetahui citra yang melekat pada setiap periode pemerintahan di Indonesia, evaluasi kerja pemerintahan bisa dengan mudah dilakukan. Semisal pada era Orde lama salah satu kolokasi yang sering muncul adalah "Nationalistic", namun kata ini tidak pernah muncul lagi di era orde baru dan reformasi, pergeseran kolokasi ini bisa mengindikasikan bahwa terjadi kemunduran kesadaran dan jiwa rakyat Indonesia mengenai cinta tanah air. Secara ilmiah, salah satu cara untuk melihat kolokasi sebuah kata adalah menggunakan corpus. Corpus merupakan serangkaian prosedur 
dan metode untuk mempelajari bahasa (McEnery\&Hardie, 2012). Dengan mengikuti prosedur dan metode dalam corpus, kolokasi kata Indonesia bisa ditemukan, kemudian dengan interpretasi lebih lanjut citra Indonesia dari orde lama hingga reformasi bisa dilihat perbedaanya.

\section{METODELOGI}

Untuk meneliti citra Indonesia, dalam tiga periode kepemimpinan, penelitian ini memiliki rentang waktu tertentu, yang disebut sebagai penelitian diakronik. Selain itu penelitian ini menggunakan corpus sebagai data, maka disebutlah sebagai diachronic corpus. Diachronic corpus yaitu sebuah korpus yang dibangun mewakili sebuah bahasa atau ragam bahasa tertentu selama periode waktu tertentu, sehingga sangat mungkin bagi peneliti untuk melacak perubahan linguistik di dalamnya (Baker, Hardie, $\&$ Mcenery, 2006). Oleh sebab itu untuk mendukung penelitian ini alat korpus yang bernama COCA merupakan pilihan paling tepat dalam meneliti kolokasi adjektiva kata Indonesia.

Penelitian ini menggunakan metode penelitian campuran atau mix method. Yaitu sebuah metode pengumpulan data dengan mengkombinasi dua elemen metode penelitian yaitu metode penelitian kualitatif dan kuantitatif (Creswell \& Clark, 2011). Dalam penelitian ini bagian dalam metode penelitian kuantitatif terdapat dalam proses komputerasisi atau proses pengambilan kolokasi adjaktiva dalam corpus tools yakni dalam COCA dan COHA. COCA dan COHA secara otomatis akan menghasilkan luaran (output) berupa kolokasi adjectiva kata Indonesia mulai dengan kolokasi berfrekuesi tinggi hingga ke frekuensi yang lebih rendah diikuti dengan data numeriknya. Analisa lanjutan mengenai persamaan, perbedaan dan konteks situasi yang mempengaruhi kemunculan kolokasi kata Indonesia nantinya dianalisis sebagai bagian dari metode penelitian kualitatif menggunakan analisis wacana (Discourse Analysis) oleh Djik (1997).

Sumber data dalam penelitian ini adalah kolokasi adjektiva kata Indonesia yang muncul dalam COCA dan COHA berdasarkan periode pemerintahan yaitu orde lama (1945-1967), orde baru (1968-1998) dan era reformasi (1999-2015). COCA dipilih sebagai corpus tools sebab kedua corpora ini berisi teks yang lengkap dari berbagai bidang seperti fiksi, tulisan akademik, majalah dan surat kabar (Universitat, 2015). Kelengkapan ketersediaan ini akan menunjang tingkat validitas kolokasi adjektiva kata Indonesia. Selain itu penelitian ini juga merupakan penelitian korpus diakronik (diachronic corpus) dengan tiga dimensi waktu sesuai dengan periode pemerintahan di Indonesia. Penggunaan COCA dan COHA diharapkan cocok digunakan dalam penelitian ini sebab input text atau data dalam COHA (Corpus of Historical American 
English) dimulai pada tahun 1810-2009 dan COCA (Corpus of Contemporary American English) pada tahun 1990-2015.

Dalam tahap pengumpulan data perlu adanya klasifikasi penggunaan corpus tools. Kolokasi kata Indonesia dalam orde lama (1945-1967) dan orde baru (19681998) menggunakan COHA mengingat ketersedian teks dalam COHA dimulai pada tahun 1810-2009. Selanjutnya dalam era reformasi (1999-2015) menggunakan COCA dengan input data dimulai pada tahun 1990-2015. Langkah kedua untuk mendapatkan kolokasi adjektiva kata Indonesia dalam kolom WORD(S) diketikkan kata "Indonesia". Kemudian dalam kolom POST LIST dipilih adj.ALL, mengingat kolokasi adjektiva merupakan kolokasi yang akan diteliti. Kemudian dalam kolom COLLOCATES pada bagian numerik, dipilih angka 1 kiri dan 0 kanan. Pemilihan kolokasi 1 kiri dan 0 kanan ini artinya kita mencari satu kata adjektiva sebelum kata Indonesia dan nol kata adjektiva setelah kata Indonesia. Langkah terakhir memilih tahun sesuai dengan sistem pemerintahan di Indonesia yakni, 1940-1960 untuk orde lama dalam COHA, 1970-1990 untuk orde lama, dalam 2000-2015 untuk era reformasi dalam COCA.

Setelah data terkumpul data ditabelkan berdasarkan periode pemerintahan agar persamaan dan perbedaan kolokasi adjektiva dapat dengan mudah dianalisa.

Kemudian data dikelompokkan kedalam kelompok kata sosial, politik, alam dan lain-lain untuk memudahkan dalam analisa citra yang melekat di setiap periode pemerintahan. Langkah-langkah pengumpulan data dapat dilihat dalam Gambar 1.

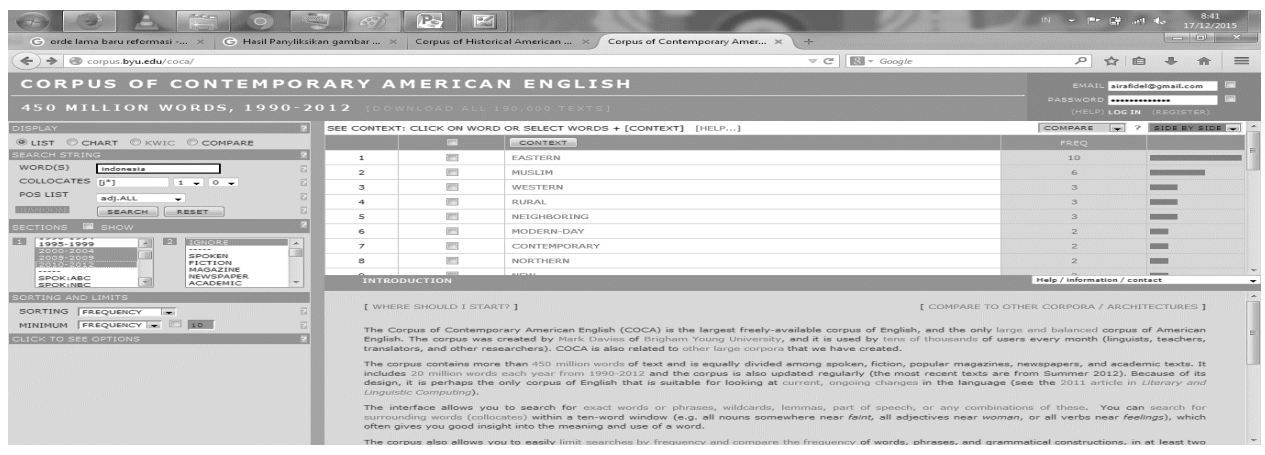

Gambar 1:Langkahlangkah Pengumpulan Data

\section{PEMBAHASAN}

\section{Kolokasi Adjektiva Kata Indonesia dalam Periode Pemerintahan Orde Lama (1945-1967)}

Era Orde lama dalam sejarah pemerintahan Indonesia dipimpin oleh Presiden pertama Indonesia, Ir. Soekarno. Dekker (1989) menyebut bawasanya pada masa orde lama, Indonesia dianggap sebagai negara baru, dengan man-power terbanyak dan terkuat, dengan wilayahnya yang terbesar, yang proklamasinya paling tegas anti 
penindasan dan falsafah kenegaraannyan benar-benar merupakan refleksi kepribadian sendiri, dengan perspektif untuk menciptakan kehidupan bangsanya yang adil dan makmur. Berdasarkan data dalam COHA, terdapat delapan kata yang merupakan kolokasi adjektiva kata Indonesia dalam periode orde lama yakni sovereign, new, nearby, nationalistic, moslem, greater, formality-conscious, catankerous. Berikut merupakan kolokasi adjektiva atau asosiasi kata yang lekat dengan kata Indonesia pada periode pemerintahan orde lama dapat dilihat dalam Gambar 1.

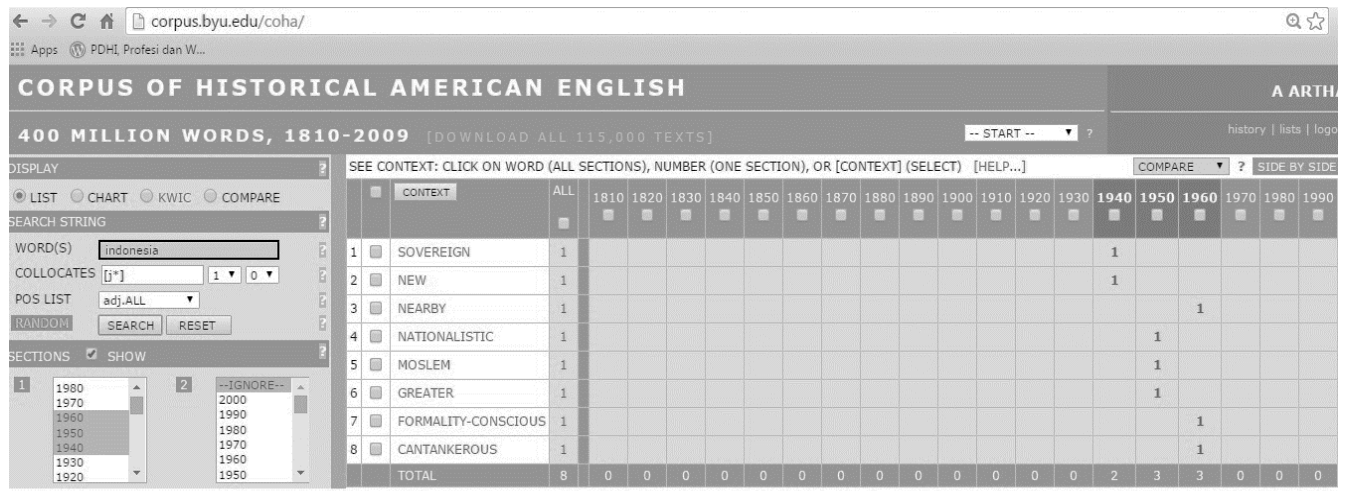

Gambar 2. Kolokasi Adjektiva Kata Indonesia dalam Periode Orde Lama

Data yang masuk dalam COHA ini merupakan hasil dari metode penelitian kuantitatif kemudian kata kata yang muncul sebagai kolokasi adjektiva ini nantinya memerlukan interpretasi dan studi lanjut menggunakan metode kualitatif dengan analisis wacana (discourse analysis) oleh Djik (1977). Untuk memudahkan analisis wacana, melihat KWIC (Keyword In Context) kata perkata sangat diperlukan agar konteks dalam text dapat dengan mudah dianalisis. Singkatnya, KWIC merupakan teknik untuk mengidentifikasi tema (Ryan \& Bernard, 2003). Artinya adalah KWIC merupakan sebuah sarana yang baik untuk memberikan gambaran mengenai kataperkata dalam fenomena bahasa yang akan dicari.

Berdasarkan data, kolokasi yang muncul pertama dengan frekuensi tertinggi adalah sovereign yang artinya berdaulat. Berdasarkan data, kata "sovereign" muncul pada tahun 1949 dengan salah satu KWIC-nya: “ economists, Dr. Sumitro, has said: "After the establishment of a sovereign Indonesia it must be our first concern to get the people back to work rather than". sovereign atau berdaulat bilamana dilihat dalam KBBI memiliki arti sebagai (1) berbahagia; bertuah (2) mempunyai kekuasaan tertinggi atas suatu pemerintahan negara atau daerah. Hal ini mengartikan bahwa "Indonesia negara berdaulat", yakni Indonesia adalah negara yang memiliki kekuasaan tertinggi atau yang berdaulat, diakui dan berbahagia.

Secara kontekstual text ini muncul setelah tiga tahun kemerdekaan Indonesia dideklarasikan. Berdasarkan sejarahnya, deklarasi kemerdekaan Indonesia terjadi 
pada tanggal 17 Agustus 1945 yang saat ini diperingati sebagai Hari Kemerdekaan Indonesia. Namun jika melihat kepada catatan sejarah, pada tahun 1945 Indonesia belum sepenuhnya merdeka, sebab Belanda masih menganggap Indonesia sebagai daerah jajahan dan belum mengakui kemerdekaan Indonesia. Catatan sejarah oleh Toer \& Kamil (1999) menerangkan bahwa proklamasi kemerdekaan tidak diketahui di semua daerah pada waktu yang bersamaan dan pada pasca kemerdekan ini banyak terjadi perebutan kekuasaan baik secara kekerasan maupun dengan jalan perundingan hingga terjadinya agresi militer Belanda. Bisa dikatakan proklamasi kemerdekaan Indonesia ini merupakan titik awal kemerdekaan Indonesia.

Sebagai negara yang baru merdeka, Indonesia melakukan pembenahan dalam segala aspek. Dalam catatan sejarah oleh Toer \& Kamil (1999), disebutkan bahwa dimulai tahun 1948, Indonesia mulai membangun ekonomi yang adil dan makmur dengan dimulainya kongres-kongres untuk kesejahteraan rakyat Indonesia seperti Kongres Serekat Buruh dll. Berdasarkan KWIC terdapat tokoh yaitu Dr. Sumitro. Dr. Sumitro merupakan Bapak Sarjana Ekonomi Indonesia yang ikut berjuang terhadap ekonomi Indonesia pasca merdeka dan merupakan salah satu staf perdana menteri Republik Indonesia Indonesia (Begawan Ekonomi Indonesia, 2014). Secara kontekstual Indonesia merupakan negara yang berdaulat dengan semangat membangun ekonomi yang tinggi.

Kolokasi kata Indonesia yang kedua adalah kata new dengan KWIC “IF INDEPENDENCE means a nation's ability to make decisions without interference, the

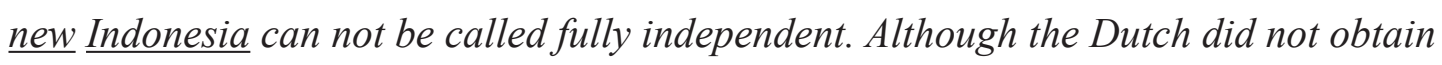
the overlordship". Kalimat ini muncul pada tahun 1949. Dikutip dalam catatan sejarah oleh Dewan Perwakilan Rakyat bahwa pada tanggal 27 Desember 1949 Belanda menyampaikan penyerahan kedaulatan secara de facto. Jadi benar bahwa Indonesia merupakan negara baru yang dianggap dunia sebagai negara yang kedaulatannya belum diakui. Kata Indonesia baru atau new Indonesia menunjukan bahwa Indonesia merupakan negara baru yang kemerdekaannya belum sepenuhnya secara de jure.

Kolokasi adjektiva yang ketiga adalah kata nearby yang muncul pada tahun 1963 dengan KWIC “ A truckload of armed guards and an armored car were stationed at the nearby Indonesia Hotel. British Embassy personnel and their families were taken to the hotel for the". kata nearby Indonesia ini merujuk pada hotel, "nearby Indonesia hotel", kemudian juga terdapat British embasy dalam KWIC COHA. Konteks yang terjadi dalam KWIC ini merupakan konteks sejarah. Bila dilihat dalam tahun luaran teks, maka ada banyak kejadian yang mungkin sesuai dengan konteks KWIC. Pertama adalah masalah konfrontasi Indonesia-Malaysia pada tahun 19631966 (Suwirta, 2010). Kejadian kedua adalah peristiwa rasialis pada tahun 10 mei 
1963 yang melibatkan provokasi imperialis yang melibatkan isu SARA.

Kolokasi adjektiva keempat yaitu nationalistic, yang mungkin memiliki konteks situasi tersembunyi. Adjektiva ini muncul pada tahun 1955 dengan KWIC “ By prewar standards especially, the lot of a foreigner in nationalistic Indonesia is not enviable, and many have left. I like to remember one Dutch". Dalam kalimat ini artinya Indonesia merupakan negara yang memiliki nasionalitas tinggi yang tidak terbantahkan, terbukti dengan adanya kalimat "nationalistic Indonesia is not enviable". Merujuk pada catatan sejarah menyebutkan bahwa pada tahun ini Indonesia merupakan negara yang stabilitas politiknya baik, Indonesia disebut sebagai negara baru yang mulai mendeklarasikan namanya dengan masuknya Indonesia sebagai anggota dari Perserikatan Bangsa Bangsa pada tanggal 27 September 1950 (Toer \& Kamil, 1999).

Kolokasi adjektiva kata Indonesia yang kelima adalah Moslem pada tahun 1956 dengan KWIC "Pakistan and Turkey, are not Arab. For that matter, neither is Moslem Indonesia. A settlement of the basic problems of operation of the suez canal in the". Secara kontekstual dalam kalimat ini menyebutkan bahwa Pakistan, Turki dan muslim di Indonesia bukan merupakan bagian dari arab. Pemilihan kata dalam kalimat ini adalah "moslem Indonesia" bukan "moslem in Indonesia, hal ini dapat diartikan bahwa Indonesia pada zaman ini diidentikan dengan moslem dan bahkan diidentikan sebagai bagian dari orang arab meskipun kenyataannya bukan. Secara kontekstual dalam pemilihan katanya dapat disimpulkan bahwa Indonesia merupakan negara dengan jumlah penduduk yang memeluk agama Islam besar, terbukti dalam kalimat ini Indonesia disamakan kedudukannya dengan negara negara Islam yang penduduknya mayoritas pemeluk agama Islam.

Kolokasi adjektiva yang mencerminkan citra positif Indonesia muncul kembali di posisi keenam yaitu kata greater pada tahun 1959 dengan KWIC “ narrower aims. The pan-malayan islamic party dreams of bringing malaya into a " greater Indonesia. " two small leftist parties formed a socialist front and advocated the expropriation of". Dalam kalimat ini secara tidak langsung disebutkan bahwa pada tahun 1959 stabilitas politik Indonesia semakin matang, yaitu dengan ditandai terbentuknya partai politik yang bernama "Malayan Islamic Party". Budiarjo (2003) menyebutkan bahwa partai politik memiliki fungsi sebagai sarana komunikasi politik, sarana sosialisasi politik dan pengatur konflik. Dengan dasar ini dapat disimpulkan bahwa semakin banyak partai politik maka stabilitas pemerintahan akan semakin baik. Dengan adanya partai politik maka informasi dari kalangan elit atau penguasa negara akan cepat sampai kepada masyarakat, dan atau aspirasi rakyat akan segera sampai kepada pusat pemerintahan dan kebijakan yang baik dan matang untuk pembangunan Indonesia bisa segera direalisasikan. 
Kolokasi adjectiva yang muncul pada periode pemerintahan orde lama tidak hanya kolokasi yang memiliki nilai positif namun kolokasi adjectiva yang negatif juga bisa terlihat. Pada kolokasi ke tujuh, yaitu formality-conscious, dalam KWIC disebutkan bahwa "that no Indonesian official saw mr. Bunker off at the airport. And in formality-conscious Indonesia - this was a direct insult to president johnson's personal representative. Mr. Jones said". Secara kontekstual Indonesia dianggap sebagai negara yang kurang menjaga relasi politiknya. Dalam KWIC ini dapat dilihat bahwa Indonesia lalai menyambut kedatangan Mr. Bunker. Berdasarkan sejarah pada sekitar tahun 1960an terjadi konfrontasi antara Indonesia dan Belanda mengenai perebutan Irian Barat, salah seorang tokoh yang memediasi konfrontasi ini adalah Mr. Bunker yang merupakan seorang duta besar Vietnam Selatan.

Kolokasi adjektiva yang terakhir adalah catankerous yang muncul pada tahun 1963 dengan KWIC "The event suggested that, at least for the time being, cantankerous Indonesia is getting to be a more responsible citizen in the Southeast Asia neighborhood". Indonesia selain disebut sebagai negara yang berdaulat, bernasionalistik tinggi, bangsa yang besar ternyata dulu sebelum tahun 1960an Indonesia juga dianggap sebagai negara yang suka membantah, dan kurang peduli dengan negara disekitarnya. Secara kontekstual dalam kalimat ini terdapat kata "is getting to be a more responsible", ini artinya seiring kematangan Indonesia sebagai negara yang diakui kedaulatannya relasi politik dan hubungan kenegaraan atar negara tetangga semakin membaik dan matang.

\section{Kolokasi Adjektiva Kata Indonesia dalam Era Orde Baru (1968-1998)}

COHA merupakan merupakan corpus tools yang datanya diklasifikan per dekade sedangkan periode orde lama dimulai pada tahun (1968-1998) artinya untuk kolokasi adjektiva yang muncul diluar tahun pemerintahan dipilah secara manual. Berbeda dengan periode orde lama, kolokasi adjective yang muncul dalam kata Indonesia sangat terbatas. Dalam periode orde baru kolokasi kata Indonesia hanya terdapat empat kata yaitu indepedent, hot, healing dan chaotic. Berikut adalah kolokasi adjektiva kata Indonesia yang muncul pada periode orde baru dapat dilihat :

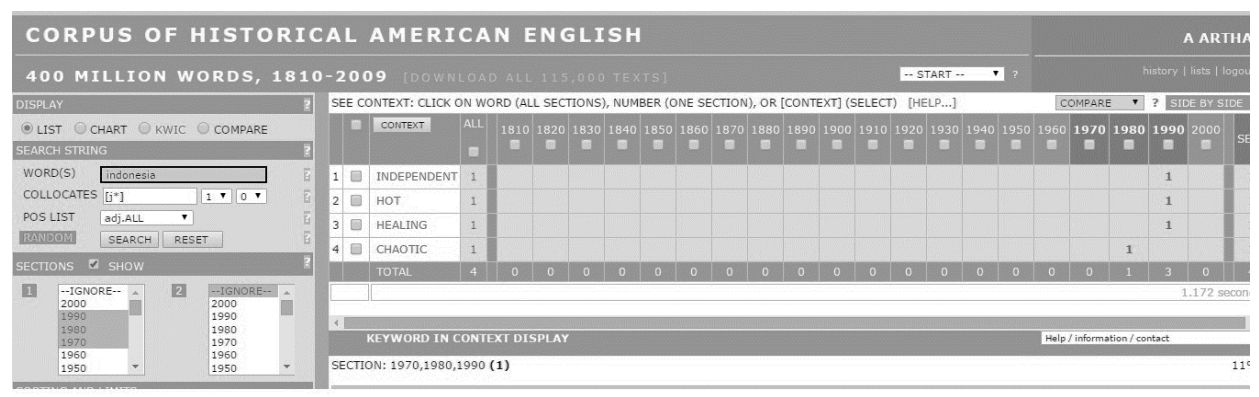

Gambar 3. Kolokasi Adjektiva Kata Indonesia dalam Periode Orde Lama 
Kolokasi pertama adalah kata Independent Indonesia yang tidak kurang menyebutkan sebagai negara yang merdeka dan mandiri. Hal ini disematkan karena pada saat pemerintahan Presiden Soeharto, Indonesia melakukan pembangunan besarbesaran untuk menunjukkan kepada khalayak dalam hal Pembangunan Nasional Indonesia (Hadi \& Kasuma, 2012). Pembangunan yang dilakukan oleh Soeharto kala itu merupakan pembangunan besar-besaran sehingga memberikan Presiden kedua ini gelar sebagai Bapak Pembangunan.

Kolokasi adjektiva kedua yang muncul dalam perode orde lama adala kata hot, dengan KWIC "so that our skin and clothes are constantly drenched. During my fieldwork in hot Indonesia, I am always surprised when my Indonesian colleagues remain comfortable in their long trousers". Kalimat ini merujuk kepada kondisi alam Indonesia. Republik Indonesia disingkat RI atau Indonesia adalah negara di Asia Tenggara, terletak di garis khatulistiwa (www.Indonesia.go.id), dengan dasar letak geografis ini maka secara langsung suhu Indonesia akan lebih panas dibanding dengan negara lain. Dalam KWIC ini satu budaya menarik yang aneh bilamana dilihat dengan budaya bangsa di luar Indonesia, yakni menggunakan celana panjang walaupun cuaca terik. Indonesia sangat menjunjung tinggi adat, dan adab, bahkan dalam adab berpakaian sekalipun. Bercelana panjang merupakan adab laki-laki untuk mengikuti dan menuruti pandangan masyarakat sebagai satu entitas negara, Indonesia.

Kolokasi adjektiva ketiga yang ditemukan adalah chaotic dengan KWIC "during a coup, in Libya under the regime of King Idris, in chaotic Indonesia and in the Libya of Col. Qadhafi. After a Christmas holiday in Michigan" yang muncul pada tahun 1981. Pada kisaran tahun ini menurut catatan sejarah menjelaskan bahwa banyak terjadi kerusuhan dan kekerasan etnis di Indonesia salah satunya adalah kerusuhan rasial terhadap warga tionghoa di Indonesia (Setyautama, 2008)

\section{Kolokasi Adjektiva Kata Indonesia dalam Era Reformasi (1999-2015)}

Untuk mendapatkan kolokasi adjektiva kata Indonesia di era reformasi, COCA adalah corpus tools yang digunakan. Secara keseluruhan terdapat 33 kolokasi adjektiva dalam periode ini, namun hanya 10 kolokasi adjektiva yang dipilih agar penelitian lebih komprehensive dan mendalam. Berikut adalah 10 kolokasi adjectiva kata Indonesia dalam COCA: 


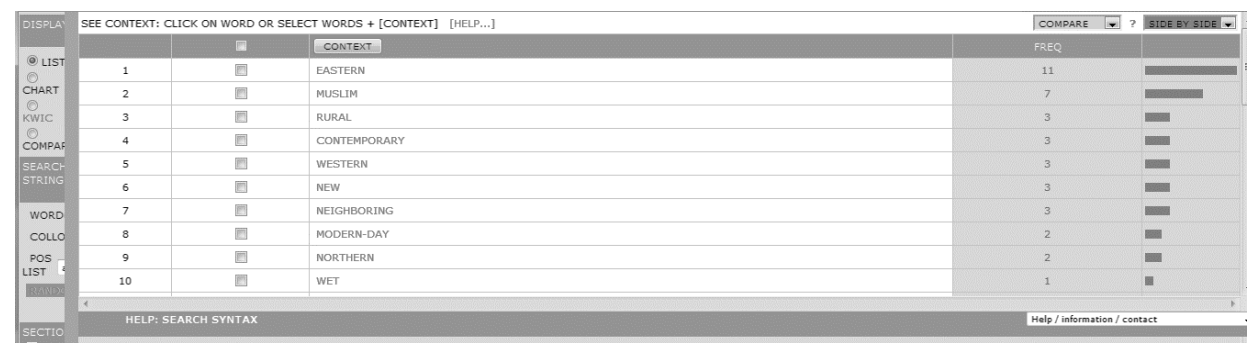

Gambar 4. kolokasi adjektiva kata Indonesia dalam periode era reformasi.

Dapat dilihat dalam tabel kolokasi adjectiva yang muncul adalah Eastern, Muslim, Rural, Contemporary, Western, New, Neighboring, Modern-Day, Northern, Wet. Berikut merupakan KWIC dari kata Eastern dan analisis dua kolokasi adjektiva kata Indonesia:

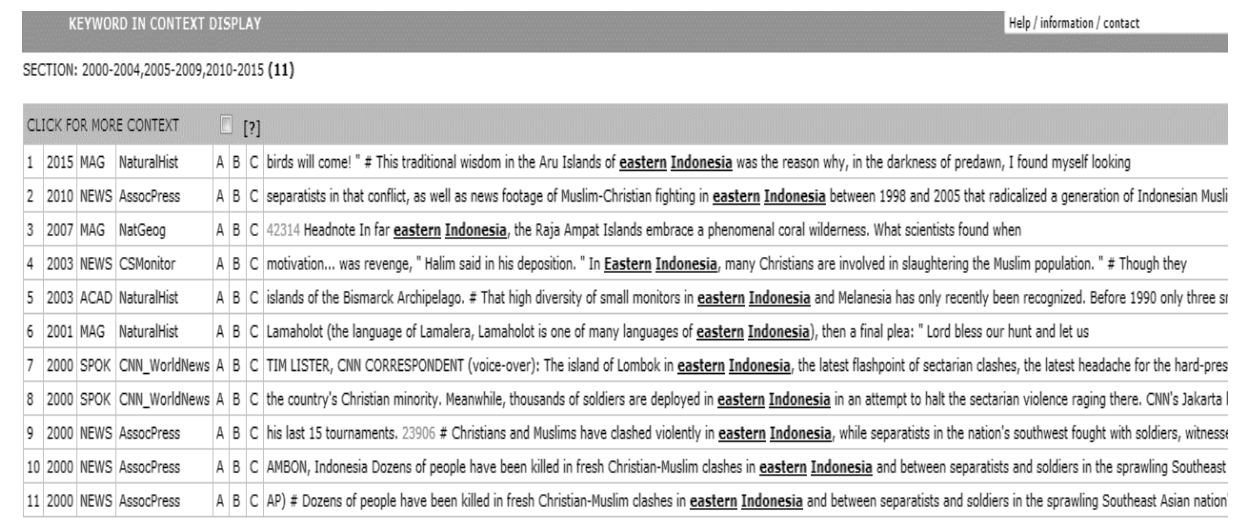

\section{Gambar 5. Kwic Kata Eastern}

Dalam KWIC yang terlihat dalam gambar diatas dapat disimpulkan bahwa eastern Indonesia ini artinya adalah wilayah Indonesia bagian timur. Jika diteliti lebih lanjut topik yang tertera dalam KWIC ini adalah mengenai christian-muslim. Dalam penggalan KWIC tersebut banyak menjelaskan mengenai konflik yang terjadi antar pemeluk agama utamanya di Indonesia wilayah bagian timur. Artinya eastern Indonesia disini mengarah pada chaotic Indonesia, hampir sama dengan orde baru. Hudayah, Nur \& Winarni, Retno (2014) menyebutkan bahwa Orde Baru merupakan sebuah periode terjadinya sentimen negatif bagi etnis Tionghoa yang mayoritas memeluk agama Kristen. Bahkan pada tahun 1959 etnis Tionghoa dituntut untuk mengubah namanya menjadi nama pribumi berdasarkan PP No.10 tahun 1959.

Indonesia amat dekat hubungannya dengan muslim, sehingga munculah Muslim Indonesia dalam urutan kolokasi kedua. Indonesia sendiri merupakan salah satu negara dengan muslim terbesar di muka Bumi (Madjid, 2007). Oleh karenanya sangat tidak mengherankan bila kata muslim sangat dekat hubungannya dengan Indonesia. 


\section{Pemetaan Kolokasi Adjektiva Kata "Indonesia" Per-periode Pemerintahan}

Dalam setiap periode pemerintahan telah terlihat bahwa kata indonesia memiliki kolokasi yang berbeda. beda. Berikut merupakan tabel untuk memudahakan menganalisa perbedaan dan persamaan kolokasi adjektiva dalam tiga dimensi periode pemerintahan di Indonesia berasarkan COCA dan COHA (Lihat Tabel 1.)

\begin{tabular}{|c|c|c|c|}
\hline No & Orde Lama & Orde Baru & Reformasi \\
\hline 1 & Sovereign & Independent & Eastern \\
\hline 2 & New & Hot & Muslim \\
\hline 3 & Nearby & Healing & Rural \\
\hline 4 & Nationalistic & Chaotic & Contemporary \\
\hline 5 & Moslem & & Western \\
\hline 6 & Greater & & New \\
\hline 7 & Formality-conscious & & Neighboring \\
\hline 8 & cantankerous & & Modern-Day \\
\hline 9 & & & Northern \\
\hline 10 & & & Wet \\
\hline
\end{tabular}

Tabel 1: Kolokasi Adjektiva Dalam Setiap Periode Pemerintahan

Berdasarkan Tabel 1. Bila diperhatikan kolokasi kata terbanyak berada dalam era reformasi (33 kolokasi), diikuti dengan era oder lama (9 kolokasi), dan yang terakhir era orde baru (4 kolokasi). Dari jumlah kolokasi yang ada, bisa diambil sebuah kesimpulan bawasanya pada era reformasi merupakan era Indonesia lebih sering disoroti oleh dunia. Sedangkan, pers sangat jarang sekali menyoroti Indonesia di masa pemerintahan orde baru.

Susilastuti (2000) menyebutkan bahwa selama pemerintahan Orde Baru, kebebasan pers di Indonesia sempat terbelenggu dan ruang gerak pers dalam menjalankan fungsinya berjalan dengan tidak baik. Lebih lanjut dijelaskan oleh Siregar (2000) bahwa era orde baru menganut norma militerisme dengan menjalankan sebuah prinsip salah satunya adalah pengendalian alam fikiran masyarakat. Dari sini, dilakukan dengan monopoli wacana melalui penguasaan alat-alat komunikasi dalam masyarakat (Siregar, 2000). Hegemoni pers terjadi di dalam negeri kala itu merupakan sebuah fakta yang tertulis, dan telah diteliti oleh banyak ahli, sejarawan, dan lain sebagainya. Namun, bilamana dilihat dari data yang didapat dari COHA, ternyata hegemoni pers mungkin saja terdadi atau berimbas diluar negeri. Logikanya adalah, pers berberan aktif dalam memberikan informasi terkini terkait kondisi, suasana, konflik maupun pencapaian Indonesia pada masa itu, seharusnya kolokasi kata indonesia dalam era orde baru dapat lebih banyak ditemukan. Sebaliknya, kolokasi kata Indonesia pada era orde baru relatif sangat sedikit.

Berdasarkan pemetaan pada tabel 1 juga dapat dilihat bahwa kolokasi adjektiva kata Indonesia berganti dalam setiap periode pemerintahan. Hanya terdapat satu 
persamaan yaitu kebermunculan kata Moslem pada orde lama dan Muslim pada era reformasi. Ada hal menarik dalam pergeseran kolokasi ini yaitu pergeseran kepenulisan kata moslem berganti menjadi muslim. Chen (2002) menjelaskan bahwa kebanyakan pembicara Inggis menganggap dua kata ini memiliki arti yang sama, namun bagi orang arab jika ditilik dengan akar bahasa arab, moslem, dan muslim merupakan dua hal yang berbeda. Muslim artinya adalah orang yang memberikan dirinya kepada Allah atau merujuk kepada seseorang yang menganut Islam dan moslem dalam bahasa Arab berarti orang yang jahat dan tidak adil, oleh karena itu penggunaan kata moslem sekarang tidak lagi digunakan.

Data yang ada kemudian dipilah kembali berdasarkan empat kategori semantik yakni politik, sosial, alam, dan lain-lain. Kategori semantik ini diharapkan dapat memudahkan tema kolokasi dalam setiap era pemerintahan. Kategori semantik dari hasil kolokasi kata Indonesia dapat dilihat dalam Tabel 2.

\begin{tabular}{|l|l|l|l|l|}
\hline Masa Pemerintahan & Politik & Sosial & Alam & Lain-Lain \\
\hline \multirow{5}{*}{ ORDE LAMA } & Sovereign & Moslem & & Nearby \\
\hline & New & & & \\
\hline & Nationalistic & & & \\
\hline & Greater & & & \\
\hline & $\begin{array}{l}\text { Fo r m a l i t y - } \\
\text { conscious }\end{array}$ & & & \\
\hline & cantankerous & & Alam & Lain-Lain \\
\hline \multirow{5}{*}{ Masa Pemerintahan } & Politik & Sosial & Healing \\
\hline \multirow{3}{*}{ ORDE BARU } & chaotic & & Alam & Lain-Lain \\
\hline & Independent & & wet & Western \\
\hline Masa Pemerintahan & Politik & Sosial & & \\
\hline \multirow{5}{*}{ ERA REFORMASI } & Contemporary & Muslim & Northern \\
\hline & New & Rural & & \\
\hline & Eastern & Modern-Day & & \\
\hline & Neighboring & & & \\
\hline
\end{tabular}

Tabel 2. Kolokasi Adjektiva Diklasifikasikan Berdasarkan Aspek Pemerintahan

Berdasarkan pemetaan dalam Tabel 2 dapat dilihat bahwa dalam orde lama aspek yang sering muncul adalah aspek politik, seperti Sovereign Indonesia, New Indonesia, Nationalistic Indonesia, Greater Indonesia, Formality-conscious Indonesia, dan Cantankerous Indonesia. Secara kontekstual adjektiva yang muncul merujuk kepada Indonesia sebagai negara yang baru dan berdaulat dengan rasa nasionalisme yang 
tinggi. Adapun hal yang menarik dalam kolokasi ini adalah kolokasi yang positif. Tepatnya empat dari enam kolokasi kata Indonesia merupakan kolokasi positif, seperti Sovereign Indonesia, New Indonesia, Nationalistic Indonesia, Greater Indonesia. Kolokasi positif ini menunjukan bahwa Indonesia ternyata memiliki citra yang sangat positif di era orde lama dalam prespektif COHA atau Amerika.

Moslem Indonesia ternyata dalam orde lama telah juga banyak disorot oleh dunia, sebagai bentuk keidentikan Indonesia. Indonesia merupakan salah satu negara dengan penduduk memeluk islam atau menjadi umat muslim terbanyak. Dilansir dalam laman online Republika dijelaskan bahwa 85\% warna negara Indonesia memeluk Islam (Putra, 2016).

Kemudian dalam era orde baru, dalam hal politik terdapat dua kolokasi yakni independent, dan chaotic. Kolokasi independent Indonesia banyak merujuk pada kondisi Indonesia yang telah merdeka, mandiri dan berkembang. Kondisi ini pantas disematkan dalam periode orde baru sebagai cikal bakal perkembangan bangsa indonesia saat ini. Orde Baru merupakan sebuah masa pembangunan Indonesia, sehingga sering disebut sebagai orde pembangunan nasional. Pada masa ini, Indonesia dituntut oleh presidennya untuk melakukan perubahan diri dalam hal pembangunan dengan berbagai cara, salah satunya swasembada beras, hingga rencana pembangunan infrastruktur terstruktur untuk pengairan atau DAS, dan lain sebagainya.

Selain itu terdapat pula kolokasi negatif dari kata indonesia pada periode pemerintahan orde baru ini, yakni chaotic. Pada keadaan alam Indonesia banyak disoroti dan banyak terjadi kerusuhan atau ketidakseimbangan politik pada periode ini. Chaotic dalam era orde lama kemungkinan disebabkan beberapa isu mengenai SARA (Amaruli \& Utama, 2015; Trinugraha, 2015), beberapa kasus konflik lokal (Hadi S. , 2007), krisis moneter, dan lain sebagainya. Kekacauan dalam hal politik ini ternyata juga banyak disoroti oleh dunia walaupun tidak secara luas, dan banyak.

Yang terakir adalah Era Reformasi. Berdasarkan KBBI Daring, reformasi memiliki pengertian sebagai perubahan secara drastis untuk perbaikan (bidang sosial, politik, atau agama) dalam suatu masyarakat atau negara (Badan Pengembangan dan Pembinaan Bahasa, 2016). Era reformasi merupakan sebuah era atau masa transisi. Ini adalah suatu saat ketika negara Indonesia yang telah merdeka dan berdaulat ini berubah; berubah menuju arah yang lebih baik lagi; membangun kedepan; memperbaiki Indonesia karena banyak hal yang perlu dibenahi dalam segala lini, seperti pada bidang sosial, politik, atau agama.

Menurut konteksnya pada era ini masih sering kali terjadi pertikaian baik antar agama maupun antar wilayah. Hal ini dibuktikan dengan adanya kolokasi eastern Indonesia. Hanya saja, isu ini tidak sebanyak pada saat dalam periode orde baru. 
Menurut catatan sejarah, beberapa reformasi agama dan sosial sudah banyak dilakukan dalam era reformasi ini.

Dalam era reformasi, ternyata tidak hanya isu politik yang sering disorot seperti halnya dalam era sebelumnya, namun persebaran kolokasi kata indonesia pada era ini lebih merata. Kata indonesia juga dekat sekali dengan sosial, seperti adanya muslim Indonesia, Rural Indonesia, dan Modern-day Indonesia. Selain itu isu alam juga ditemukan seperti dalam kolokasi wet Indonesia. Hal ini menunjukkan bahwa eksistensi Indonesia ternyata sudah mulai ketara dikancah Internasional. Meskipun demikian, berbeda dengan kolokasi yang muncul pada era orde lama, era reformasi ini sangat minim dengan kolokasi positif. Oleh karenanya kolokasi yang muncul saat ini, di era reformasi ini dapat menjadi sebuah sarana perbaikan citra Bangsa, Indonesia, agar bisa memiliki citra lebih positif lagi dalam kancah nasional, maupun internasional.

\section{KESIMPULAN}

Dalam artikel ini dapat disimpulkan bahwa kolokasi adjektiva yang mengikuti kata Indonesia berganti setiap periode pemerintahan. Pergantian ini banyak dipengaruhi oleh konteks situasi atau catatan sejarah yang terjadi pada setiap periode. Dalam periode Orde Baru dalam bidang politik Indonesia lebih dikolokasikan sebagai negara yang merdeka, baru dan berdaulat, sedangkan dalam Orde Lama Indonesia dianggap sebagai negara yang independent atau mandiri meskipun ada beberapa kekacauan bidang politik. Kemudian, di Era Reformasi politik di Indonesia dianggap sebagai negara dengan politik yang cukup baik dengan selalu menjaga komunikasi politik antar negara. Dalam bidang sosial pada Orde Lama Indonesia identik sebagai negara yang penduduknya memeluk agama islam terbanyak, sedangkan dalam Era Reformasi status sebagai negara dengan pemeluk islam terbanyak namun juga sebagai negara yang identik dengan konflik antar agama. Perbedaan kolokasi diakronik berdasarkan era pemerintahan ini kemungkinan disebabkan oleh kondisi politik, sosial yang berbeda setiap tahunnya.

\section{DAFTAR PUSTAKA}

Begawan Ekonomi Indonesia. (2014, 4 may). Dipetik january 6, 2016, dari tokoh indonesia: http://www.tokohindonesia.com/biografi/article/285ensiklopedi/4174-begawan-ekonomi-indonesia

Amaruli, R. J., \& Utama, M. P. (2015). KONVERSI AGAMA DAN FORMASI IDENTITAS:Tionghoa Muslim Kudus Pasca-Indonesia Orde Baru. 
HUMANIKA, 103-113.

Bahasa, B. P. (2016 ). KBBI Daring. Dipetik May 14, 2018, dari kbbi.kemendikbud: https://kbbi.kemdikbud.go.id/

Baker, P., Hardie, A., \& Mcenery, T. (2006). A Glossary Of Corpus Linguistics. Edinburgh: UK.

Budiarjo, M. (2003). Dasar Dasar Ilmu Politik. Jakarta: Gramedia Pustaka Utama.

Chen, Y.-A. C. (2002, August 7). History News Network. Dipetik may 14, 2018, dari history news network: https://historynewsnetwork.org/article/524

Ginting, R., \& Haryati, T. (2011). REFORMASI BIROKRASI PUBLIK DI INDONESIA. CIVIS, 27-41.

Hadi, D. W., \& Kasuma, G. (2012). Propaganda Orde Baru 1966-1980. Verleden, 4049.

Hadi, S. (2007). Disintegrasi pasca Orde Baru: negara, konflik lokal, dan dinamika internasional. Jakarta: Yayasan Obor Indonesia.

Hudayah, N., \& Winarni, R. (2014). PENGARUH KEBIJAKAN PEMERINTAH INDONESIA TERHADAP KEHIDUPAN ETNIS TIONGHOA DI BIDANG POLITIK, SOSIAL BUDAYA,DAN EKONOMI DI KABUPATEN JEMBER DARI ZAMAN ORDE LAMA SAMPAI ZAMAN REFORMASI PADA TAHUN 1998-2012. Publika Budaya, 19-31.

Kennedy, G. (2003). Amplifier collocations in the British National Corpus: Implications for English language teaching. Tesol Quarterly, 467-487.

Kewarganegaraan, D. P. (2017, February 13). CivicPedia. Dipetik may 11, 2018, dari Kamus PKn UPI: http://kamuspkn.upi.edu/materi-141-sejarah-terbentuknyanegara-kesatuan-republik-indonesia.html

Madjid, N. (2007). Islam Universal. Yogyakarta: Pustaka Pelajar.

Putra, E. P. (2016, January 9). Republika. Dipetik may 14, 2018, dari Nasional republika: http://nasional.republika.co.id/berita/nasional/umum/16/01/09/ o0ow4v334-persentase-umat-islam-di-indonesia-jadi-85-persen

Ryan, G., \& Bernard, H. R. (2003). Techniques to Identify Themes. Field Method, Sage.

Samuel, H. (2010). Universitas, Negara, dan Masyarakat Indonesia: Implementasi Paradigma Modernisasi di Era Orde Baru. Humaniora, 31-42.

Setyautama, S. (2008). Tokoh-tokoh etnis Tionghoa di Indonesia. Jakarta: Gramedia.

Siregar, A. (2000). Media Pers dan Negara: Keluar dari Hegemoni. Jurnal Ilmu Sosial dan Ilmu Politik, 171-196.

Stubbs, M. (2009). echnology and phraseology: With notes on the history of corpus linguistics. Dalam U. Römer, \& R. Schulze, Exploring the Lexis-Grammar 
Interface (hal. 15-31). Amsterdam: Benjamins.

Susilastuti, D. (2000). Kebebasan Pers Pasca Orde Baru. Jurnal Ilmu SSosial dan Ilmu Politik, 221-241.

Suwirta, A. (2010). Dua Negara-Bangsa Melihat Masa Lalunya: Konfrontasi Indonesia -Malaysia (1963-1966) sebagaimana Dikisahkan dalam Buku-buku Teks Sejarahnya di Sekolah . Sosiohumanika, 243-258.

Toer, K. S., \& Kamil, E. (1999). Kronik revolusi Indonesia: 1948. Jakarta: Gramedia. Tony McEnery, Andrew Hardie. (2012). corpus linguistics. UK: Cambridge.

Trinugraha, Y. H. (2015). Politik Identitas Anak Muda Minoritas: Ekspresi Identitas Anak Muda Tionghoa melalui Dua Organisasi Anak Muda Tionghoa di Surakarta Pasca Orde Baru. JURNAL STUDI PEMUDA, 172-186.

Universitat, J. G. (2015, January 20). More Information about COCA and COHA. Dipetik May 16, 2017, dari english-linguistics: http://www.english-linguistics. uni-mainz.de/380.php 